ROCZNIKI TEOLOGICZNE

Tom LXVI, zeszyt 4 - 2019

DOI: http://dx.doi.org/10.18290/rt.2019.66.4-6

PAWEŁ ZAJĄC OMI

\title{
DUCHOWE IUNCTIM. POWIERZENIE PRZEZ BISKUPA SIEDLECKIEGO HENRYKA PRZEŹDZIECKIEGO PARAFII I SANKTUARIUM W KODNIU MISJONARZOM OBLATOM MARYI NIEPOKALANEJ W 1927 R.
}

\author{
SPIRITUAL IUNCTIM. BISHOP OF SIEDLCE, HENRYK PRZEŹDZIECKI, \\ AND THE ARRIVAL OF MISSIONARY OBLATES OF MARY IMMACULATE \\ TO THE PARISH AND MARIAN SHRINE IN KODEŃ IN 1927
}

\begin{abstract}
A b s t r a c t. The territory of the diocese of Siedlce has witnessed severe religious persecution in the second part of the $19^{\text {th }}$ century. The Russian authorities confiscated Catholic churches and violently forced the eastern-rite Catholics to forsake the union with the bishop of Rome and to join the Orthodox Church. A famous $17^{\text {th }}$-century image of Our Lady of Koden was removed from the church and transported to another Marian shrine in the southern Poland. Only the Polish independence in 1918 allowed the process of rebuilding the traditional religious structures to begin. The article shows the involvement of the bishop of Siedlce in restoring the image of Our Lady of Koden to its original location and the beginning of pastoral ministry of the Missionary Oblates of Mary Immaculate at the service of the Marian shrine and parish in Koden, including the attempts to restore the structures of the eastern-rite Catholic Church.
\end{abstract}

Key words: Kodeń; religious persecution; Siedlce; Bishop Henryk Przeździecki; Missionary Oblates of Mary Immaculate.

Decyzja biskupa siedleckiego Henryka Przeździeckiego o powierzeniu parafii i sanktuarium w Kodniu Misjonarzom Oblatom Maryi Niepokalanej sytuuje się w podwójnym kontekście - najpierw odbudowy struktur diecezji siedleckiej, czyli podlaskiej, po 1918 r., następnie zaś dynamicznego rozwoju istniejącej formalnie

Dr hab. Paweł ZAJĄC OMI - Uniwersytet im. Adama Mickiewicza w Poznaniu, Wydział Teologiczny, Zakład Teologii Patrystycznej i Historii Kościoła, ul. Wieżowa 2/4, 61-111 Poznań; adres do korespondencji - e-mail: pawel.zajac@amu.edu.pl 
od 1925 r. Polskiej Prowincji Misjonarzy Oblatów Maryi Niepokalanej ${ }^{1}$. Gdy spoglądamy na dwie kartki z kalendarza roku 1927, tj. 25 maja (dzień, kiedy to „peculiaris conventio [fuit] inita et signata a Nobis [Episcopo Siedlecensi] cum Superioribus eiusdem Congregationis”) oraz 4 września (dzień ponownego umieszczenia obrazu Matki Bożej Kodeńskiej w dzisiejszej bazylice oraz wręczenia dekretu o powierzeniu kodeńskiego sanktuarium i parafii Misjonarzom Oblatom) ${ }^{2}$, tego rodzaju refleksja staje się niezbędna. W dekrecie z 4 września bp Przeździecki wyznał, iż od początku swej posługi ze szczególną troską spoglądał na Kodeń: „Inde ab exordio Nostri muneris pastoralis in hac dioecesi nihil antiquius habuimus nec nunc quidem habemus, ut et ecclesiae Kodnensi pristinum splendorem restitueremus et Imaginem tam caram Gratiosissime Deiparae de novo in Kodeń exhiberemus"3. . Dekret ów, jak i poprzedzająca go umowa z 25 maja, były wynikiem rozmów podjętych z polskimi Misjonarzami Oblatami Maryi Niepokalanej, do których doszło w szczególnym momencie ich historii - fakt propozycji objęcia sanktuarium Maryjnego tej rangi oblaci uznali wówczas za opatrznościowy znak błogosławieństwa dla ich gorliwej posługi w odrodzonej Ojczyźnie.

W poniższym szkicu pominę fakty związane ze staraniami bpa Henryka Przeździeckiego o ponowne sprowadzenie do Kodnia obrazu Matki Bożej Kodeńskiej, przechowywanego od czasu rosyjskich represji w drugiej połowie XIX w. na Jasnej Górze. Opracowaniu innego autora pozostawię także fascynujący opis drogi powrotnej obrazu, z jej kulminacją w kodeńskich uroczystościach 3 i 4 września 1927 r. ${ }^{4}$ Choć bez tych wydarzeń zapewne nie doszłoby do objęcia kodeńskiego sanktuarium i parafii przez Misjonarzy Oblatów Maryi Niepokalanej, celem moim będzie jedynie wskazanie na spójność wizji duszpasterskiej biskupa siedleckiego oraz założeń oblackiego charyzmatu. Owa zgodność zaowocowała pomyślnym uwieńczeniem rozmów podjętych w sprawie powierzenia zakonnikom opieki nad parafią i sanktuarium w Kodniu.

\footnotetext{
${ }^{1}$ Przypomnijmy najważniejsze daty wyznaczające proces powstawania Polskiej Prowincji Misjonarzy Oblatów Maryi Niepokalanej: 6 czerwca 1920 r. wspólnota w Krotoszynie przestała być zależna od Prowincji Niemieckiej i została podporządkowana bezpośrednio administracji generalnej w Rzymie; 22 lutego 1922 r. utworzono Wikariat Polski, a 13 czerwca 1925 r. został on podniesiony do rangi prowincji zakonnej. Zob. P. ZAJĄC OMI, Fundacje klasztorów Misjonarzy Oblatów Maryi Niepokalanej w Archidiecezji Poznańskiej w latach 1922-1939, „Ecclesia. Studia z dziejów Wielkopolski” 5(2010), s. 147-171. Choć ,prowincja” istniała formalnie od 1925 r., oblaci polscy za jej początek przyjmują rok 1920.

${ }^{2}$ Oryginał dekretu w Archiwum Polskiej Prowincji Misjonarzy Oblatów Maryi Niepokalanej w Poznaniu [dalej: APP], Domy Prowincji, Kodeń /I/.

${ }^{3}$ Tamże.

${ }^{4}$ Zob. L. GŁOWACKI, Wywiezienie i powrót Matki Bożej Kodeńskiej. Opowieść historyczna z okazji 90. rocznicy powrotu Obrazu Matki Bożej Kodeńskiej z Częstochowy do Kodnia [praca przygotowywana do druku, mps w posiadaniu autora].
} 
Zanim pokrótce omówię oba konteksty okalające wskazane wyżej daty - 25 maja i 4 września 1927 r. - zwrócę zwięźle uwagę na dotychczasowe dociekania historyczne owym kontekstom poświęcone. Pośród licznych prac szczegółowych, najczęściej w formie artykułów naukowych i popularnonaukowych, trzy najważniejsze ujęcia syntetyczne przedwojennych dziejów diecezji siedleckiej opublikowali dotąd ks. Piotr Aleksandrowicz ${ }^{5}$, ks. Leon Balicki ${ }^{6}$ oraz Rafał Dmowski - we wstępie do tej ostatniej pracy autor szczegółowo omówił całość historiografii diecezji siedleckiej ${ }^{7}$. Co do historii Misjonarzy Oblatów Maryi Niepokalanej w okresie przedwojennym, wciąż jedyna dostępna synteza ma charakter popularnonaukowy ${ }^{8}$, choć niedawno rozpoczęto bardziej szczegółowe badania, prezentowane na razie $w$ formie artykułów naukowych ${ }^{9}$. Opublikowano ponadto wyniki oblackich dociekań dotyczących historii obrazu Matki Bożej Kodeńskiej $^{10}$. Wokół dziejów Kodnia i parafii kodeńskiej powstało też szereg prac magisterskich $^{11}$, a także niepublikowanych szkiców i wypisów źródłowych na prawie maszynopisu ${ }^{12}$.

Podstawowe fakty dotyczące genezy kodeńskich wydarzeń 1927 r. oraz działalności oblatów w Kodniu w późniejszych latach są dobrze znane. Jak pisał ks. Balicki, „diecezja siedlecka, czyli podlaska, ma historię stosunkowo niedługą, ale dość burzliwą i nietypową"13. Powtórzę za cytowanym autorem jej najważniejsze etapy. Papież Pius VII bullą z 2 VII 1818 wyznaczył Janów Podlaski na stolicę nowej diecezji - podlaskiej, czyli janowskiej. Dziedziczyła ona tradycje 5 diecezji dawnej Rzeczypospolitej: krakowskiej, poznańskiej, łuckiej, płockiej i chełmskiej - z części ich terytorium w 1805 r. powstała diecezja lubelska i to $\mathrm{z}$ niej bezpośrednio wydzielono w $1818 \mathrm{r}$. diecezję podlaską ${ }^{14}$. Car Aleksander II

\footnotetext{
${ }^{5}$ P. Aleksandrowicz, Diecezja Siedlecka czyli Podlaska. W 150 rocznice erekcji (1818-1968). Przyczynki i materiaty do dziejów Diecezji Siedleckiej czyli Podlaskiej, Siedlce 1971.

${ }^{6}$ L. BALICKI, Dzieje gospodarcze diecezji siedleckiej, 1918-1939, Lublin 1991.

${ }^{7}$ R. DMOwski, Unitis Viribus. Diecezja Podlaska w II Rzeczypospolitej, Warszawa 2013.

${ }^{8}$ J. PIELORZ OMI, Oblaci polscy. Zarys dziejów prowincji 1920-1970, Rzym 1970.

${ }^{9}$ Zob. P. ZAJĄC OMI, Fundacje klasztorów Misjonarzy Oblatów Maryi Niepokalanej w Archidiecezji Poznańskiej w latach 1922-1939, s. 147-171; TENŻE, Badania historyczne w polskim środowisku Misjonarzy Oblatów Maryi Niepokalanej, ,Roczniki Historii Kościoła” 3(2011), s. 147-170.

${ }^{10}$ J. PIELORZ, Obraz Matki Boskiej Kodeńskiej na tle legendy i historii, Liège-Rzym 1996.

${ }^{11}$ Zob. przykładowo: G. MARECKI, Działalność Misjonarzy Oblatów Maryi Niepokalanej w Kodniu w latach 1927-1939, Poznań 2009, mps mgr [Wydział Teologiczny UAM, promotor P. Zając OMI].

${ }^{12}$ Zob. przykładowo: J. JASTRZĘBSKI, Kodeń. Szkic historii parafii katolickiej, b.m., 1985, mps w Bibliotece WSD Misjonarzy Oblatów Maryi Niepokalanej w Obrze; J. KRAwCZYK, Źródta, Lublin 1968-1978, 11 t., passim.

${ }^{13}$ L. BALICKI, Dzieje gospodarcze, s. 7.

${ }^{14}$ Dalsze szczegółowe informacje zob.: P. Aleksandrowicz, Diecezja Siedlecka czyli Podlaska, s. 23nn.
} 
22 V 1867 r. zdecydował o kasacie diecezji i włączeniu jej na powrót do diecezji lubelskiej, co usankcjonował kanonicznie papież Leon XIII 30 XII 1889 r. Odzyskanie przez Polskę niepodległości umożliwiło odrodzenie diecezji podlaskiej, co nastąpiło decyzją papieża Benedykta XV jeszcze 24 IX 1918 r. Odtwarzanie struktur diecezjalnych 100 lat po pierwszym powołaniu ich do życia dokonywało się ze świadomością szczególnego bagażu doświadczeń minionych dziesięcioleci - represje rosyjskiego zaborcy naznaczyły diecezję tradycją męczeńską ${ }^{15}$, ale także skomplikowały jej praktyczne funkcjonowanie. Dotyczyło to zwłaszcza praw własności kościołów odebranych unitom po 1875 r. Stały się one wówczas świątyniami prawosławnymi, by po 1918 r. doczekać się rewindykacji na rzecz Kościoła rzymskokatolickiego, lecz już obrządku łacińskiego, do którego po 1905 r. powracali dawni unici, w drugiej połowie XIX w. włączani siłą do Kościoła prawosławnego ${ }^{16}$.

W latach 1918-1939 bp Przeździecki doprowadził w diecezji siedleckiej do podwojenia liczby dekanatów (z 9 do 20), podwojenia liczby kościołów parafialnych (ze 110 do 233), podwoiła się także liczba kapłanów diecezjalnych (ze 189 do 409). Odbudowane zostało w diecezji życie konsekrowane - ze stanu zerowego liczba kapłanów zakonnych w 1939 podniosła się do 30, a sióstr zakonnych do $107^{17}$. Były to osiągnięcia imponujące.

W 20-lecie swej posługi biskupiej bp Przeździecki wystosował do duchowieństwa i wiernych diecezji siedleckiej list pasterski, w którym dokonał osobistego podsumowania przebytej drogi. Pierwsza część listu to zaskakujące modlitewne zwrócenie się do zmarłych diecezjan - biskup dał wyraz swemu najgłębszemu pragnieniu: żeby wierni, którym przewodził od 20 lat, mogli cieszyć się chwałą zbawionych $w$ niebie. Nie rozpoczął więc od wykazania danych statystycznych, mogących świadczyć o jego geniuszu organizacyjnym, ale dziękował swym diecezjanom w niebie, że „bohatersko znosili prześladowania w obronie wiary”, że wyrzekali się pijaństwa, dobrze wychowywali dzieci, byli „dla nich wzorem życia według nauki Chrystusowej, byli wiernymi małżonkami, nie nurzali się w rozpuście, nie krzywdzili bliźnich, miłowali ich. Nie tracili wiary przez rozmowy złe, gorszące. Nie brali udziału w stowarzyszeniach występujących przeciwko Bogu i nauce Jego. Byli pracowici i czyści. Jednym słowem starali się żyć wg nauki Chrystusowej”" ${ }^{\prime 8}$. Podziękowanie biskupa rozciągało się

\footnotetext{
${ }^{15}$ Zob. K. MAtwiejuK, Błogostawieni Męczennicy Podlascy, Siedlce 1997.

${ }^{16}$ L. BALICKI, Dzieje gospodarcze, s. 7-8.

${ }^{17}$ Tamże, s. 8.

${ }^{18}$ H. PrZeźDZIECKI, Listy pasterskie i przemówienia, 1928-1938, Siedlce 1938, [LXVI, Na dwudziestolecie objęcia rządów w diecezji Podlaskiej], s. 384-385.
} 
dalej na członków Akcji Katolickiej, organizacji charytatywnych, stowarzyszeń wstrzemięźliwości i abstynencji, tych, którzy wrócili do jedności kościelnej itd. ${ }^{19}$ Na tym wydawała się polegać istota programu duszpasterskiego, którego realizację rozpoczął z końcem 1918 r. w odnowionej diecezji siedleckiej jej pierwszy biskup - doprowadzić diecezjan do pełni komunii z Bogiem w niebie.

Urzeczywistnienie tego ideału domagało się jednak działań praktycznych: przede wszystkim powiększenia liczby parafii, dekanatów, duchowieństwa diecezjalnego i zakonnego (do 1938 r. wyświęcono w diecezji 251 kapłanów), sióstr zakonnych. Celem biskupa było osiągnięcie sytuacji, w której wierni mieliby najwyżej 3 kilometry do kościoła ${ }^{20}$. Biskup radował się z korzystnej statystyki sakramentów św.: 406594 bierzmowanych; 39531870 Komunii św. („ok. 4 Komunie rocznie na każdego diecezjanina, licząc od 7 lat wieku"). Zmartwieniem biskupa pozostawały jednak wciąż parafie, w których frekwencja przy Komunii św. nie była zadowalająca ${ }^{21}$.

Szczególnym polem działalności biskupa Przeździeckiego była neounia. Osiągnięcia w tym wymiarze nie były jednak duże: „w 10 parafiach obrządku bizantyńsko-słowiańskiego żyło 1812 parafian”. Jednocześnie biskup był daleki od zniechęcenia w tym dziele. Był przekonany, że wzorem objawienia się Ducha św. w dniu Pięćdziesiątnicy „Kościół Chrystusa nie narzuca języka w głoszeniu słowa Bożego, nie narzuca obrządku"22. Tak samo w dziele pracy nad jednością Kościoła biskup zachęcał do łagodności: „Niech z ust Waszych nie padnie ostre słowo na braci nie należących do jedności kościelnej. Bądźcie dla nich zawsze uprzejmi, pogodni, w razie potrzeby pomagajcie według Waszej możności. Chrystus nie siłą pociągał i pociąga ku Sobie, lecz miłością. Naśladujmy Zbawiciela naszego" ${ }^{, 23}$. Dodawał wreszcie: „Niech dla Was, najmilsi, obrządek wschodni będzie tak drogi, jak drogim jest łaciński. Wszystkie obrządki są święte" ${ }^{\text {"24. }}$

Do praktycznych dróg prowadzenia wiernych do Boga należały bractwa i stowarzyszenia, zwłaszcza Akcja Katolicka. Ważnym zadaniem chrześcijan w świecie była walka o wolność od zniewoleń i uzależnień, przede wszystkim od alkoholu. Istotnym elementem struktury parafii miał być tzw. dom katolicki „miejsce, gdzie parafianie mogą się zbierać na wspólne narady, na rozmowy, na akademie, na zebrania towarzyskie", wierni mieli być zachęcani do czytania prasy

\footnotetext{
${ }^{19}$ Tamże, s. 385.

${ }^{20}$ Tamże, s. 387-388.

${ }^{21}$ Tamże, s. 388-389.

${ }^{22}$ Tamże, s. 389-390.

${ }^{23}$ Tamże, s. 390.

${ }^{24}$ Tamże.
} 
i książek katolickich, do angażowania się w działalność charytatywną - „w każdej parafii powinna być Caritas parafialna!"25

Konkludując swe przemówienie jubileuszowe biskup Henryk zwrócił uwagę na konieczność gorliwego świadectwa chrześcijańskiego w szczególnie trudnych czasach, które opisał słowami Piusa XI: „Narody znajdują się w przerażającym niebezpieczeństwie popadnięcia na nowo w barbarzyństwo, okropniejsze, aniżeli to, w którym większa część świata znajdowała się przed przyjściem Zbawiciela świata”26.

W cytowanej mowie biskup siedlecki nie wyróżnił żadnej konkretnej parafii, sanktuarium, zakonu czy duszpasterza. Spoglądał na całą diecezję, na dokonania minionych 20 lat, na pracę, która jeszcze pozostawała do wykonania. Tym bardziej interesujące może się okazać przypomnienie okoliczności powrotu obrazu Matki Bożej Kodeńskiej do Kodnia oraz powierzenia sanktuarium i parafii kodeńskiej Misjonarzom Oblatom Maryi Niepokalanej, jako ilustracja ogólnych założeń duszpasterskich bpa Henryka Przeździeckiego w konkretnym przykładzie jego działań i ich następstw ${ }^{27}$. Zarysowane wyżej tło refleksji bpa Henryka Przeździeckiego w 20-lecie objęcia rządów diecezją pozwoli także lepiej zrozumieć jego oczekiwania wobec zgromadzenia zakonnego, które zgodziło się przyjąć propozycję posługi w sanktuarium i parafii kodeńskiej.

Oczekiwania te w naturalny sposób wiązały się z całokształtem programu duszpasterskiego biskupa, ale szybko się okazało, że w pełni odpowiadają także oblackiemu charyzmatowi. Jego realizacja w Polsce, rozpoczęta w 1919 r. i będąca dziełem grupy doświadczonych polskich misjonarzy, działających uprzednio w Kanadzie i w Niemczech, na przełomie 1926 i 1927 r. nabrała wyjątkowego dynamizmu. Po krótkim, lecz owocnym epizodzie pracy w Piekarach Śląskich, w latach 1920-1926 powstały pierwsze stałe oblackie wspólnoty formacyjne i misyjne w Krotoszynie (1920-1922), Markowicach (1921-2013), Lublińcu (1922-), Krobi (1922-), Obrze (1926-) ${ }^{28}$. W 1926 r., a zatem rok po formalnym utworzeniu Polskiej Prowincji Misjonarzy Oblatów Maryi Niepokalanej, o. prowincjał Franciszek Kowalski po raz pierwszy wziął udział w kapitule generalnej Zgromadzenia

\footnotetext{
${ }^{25}$ Tamże, s. 391-396 (o domach katolickich zob. s. 393-394, o Caritas parafialnej zob. s. 394-395).

${ }^{26}$ Tamże, s. 397.

${ }^{27}$ Fakty te były przywoływane wielokrotnie, ostatnio także w pracy magisterskiej napisanej pod moim kierunkiem przez G. Mareckiego (zob. wyżej). W niniejszym opracowaniu sięgam bezpośrednio do źródeł z Archiwum Polskiej Prowincji Misjonarzy Oblatów Maryi Niepokalanej w Poznaniu oraz Archiwum Diecezjalnego w Siedlcach, uzupełniając znane fakty o dodatkowe informacje oraz wypisy źródłowe z korespondencji oblatów i bpa Henryka Przeździeckiego.

${ }^{28}$ Zob. P. ZAJĄC OMI, Fundacje klasztorów, passim.
} 
w Rzymie ${ }^{29}$. W styczniu 1927 r. oblaci zaczęli rozważać korzystną propozycję nabycia obszernego terenu na przedmieściach Poznania, dokąd zamierzano przenieść siedzibę administracji prowincjalnej ${ }^{30}$. I oto już 2 lutego tego samego roku kolejne posiedzenie Rady Prowincjalnej przyniosło na pierwszym miejscu następującą kwestię:

Ks. Biskup Przeździecki z Siedlec ofiaruje nam objęcie miejsca pątniczego Kodeń pod Brześciem Litewskim i żąda odpowiedzi w ciągu miesiąca, czy przyjmujemy, czy nie. Rada Prowincjalna wypowiada się jednogłośnie za przyjęciem, ze względu: 1. na sławę owego miejsca, 2. na doniosłość jego jako okna na wschód dla naszej prowincji. O. Prowincjał napisze do ks. Biskupa Siedleckiego, że Rada Prowincjalna w zasadzie godzi się na objęcie Kodnia, ale że Administracja Generalna żąda przed ostateczną aprobatą dokładnych danych, żeby wobec tego ks. Biskup nam pozwolił obiekt ten poprzednio osobiście zwiedzić ${ }^{31}$.

Te ustalenia Rady o. prowincjał Franciszek Kowalski przekazał bpowi Przeździeckiemu w liście z 3 lutego 1927 r. ${ }^{32} 26$ marca w kolejnym liście donosił o przychylności Rady Generalnej dla projektu objęcia przez oblatów parafii sanktuarium w Kodniu. Prowincjał informował i prosił:

uprzejmie o łaskawe przysłanie propozycji ugody pomiędzy Stolicą Biskupią i Zgromadzeniem, albo o wyznaczenie miejsca i czasu na pertraktacje z pełnomocnikiem Waszej Ekscelencji. Zwiedziłem Kodeń, skąd wróciłem zadowolony. Czeka nas tam wielka i ciężka praca, ale właśnie to zachęciło nas do przyjęcia łaskawej propozycji Waszej Ekscelencji, gdyż chcemy poświęcić się tej pracy w myśl hasła Zgromadzenia: „Evangelizare pauperibus misit me". Przytem jako Oblaci Marji Niepokalanej cieszymy się, że Wasza Ekscelencja przeznaczyła nam zaszczytne zadanie pracowania około wskrzeszenia wiary i nabożeństwa do Matki Najświętszej w Kodniu ${ }^{33}$.

${ }^{29}$ Zob. P. ZAJĄC OMI, „Wobec wielkich potrzeb naszego wychodźstwa...”. Polscy Misjonarze Oblaci Maryi Niepokalanej w perspektywie Kapituły Generalnej 1926 r., „Studia Polonijne” 33(2012), s. $117-140$.

${ }^{30}$ Rada Prowincjalna w Poznaniu, 12 I 1927 [Wyciąg z protokołów Rady Prowincjalnej], w: J. KRAWCZYK, Źródta, t. 2, Lublin 1969, mps w APP, s. 50.

${ }^{31}$ Tamże, s. 50.

${ }^{32}$ F. Kowalski do H. Przeździeckiego, Krobia, 3 II 1927, Archiwum Diecezjalne w Siedlcach [dalej: ADS], Akta Kurii Diecezji Podlaskiej, Zgromadzenie Misjonarzy Oblatów w Kodniu, N.Z.8. [Dalej: Kuria/OMI]. Dziękuję ks. mgr lic. Janowi Babikowi za życzliwe udostępnienie archiwaliów z Archiwum Diecezjalnego w Siedlcach.

${ }^{33}$ F. Kowalski do H. Przeździeckiego, Krobia, 26 III 1927, ADS, Kuria/OMI. 
W maju o. Kowalski spędził kilka dni w Siedlcach, ustalając z biskupem treść umowy w sprawie Kodnia ${ }^{34}$. Została ona podpisana 25 maja 1927 r. (3 kwietnia 1933 uzupełniono niektóre jej zapisy, dotyczące zwłaszcza kwestii rozliczeń stypendiów i dochodów parafii i klasztoru) ${ }^{35}$. Duszpasterskie oczekiwania biskupa zostały wyrażone zwięźle. Oblaci mieli „prowadzić miejscową parafię i dawać misje oraz rekolekcje w parafiach diecezji Podlaskiej, a ewentualnie w sąsiedniem Zabużu”. Ponadto mieli się starać „o pracę w obrządku wschodnio-katolickim dla wiernych tego obrządku w diecezji Podlaskiej”36. Stopniowe przejmowanie obowiązków dotychczasowego administratora parafii Kodeń, ks. Stanisława Tuza, przebiegało początkowo $\mathrm{w}$ dobrej atmosferze - o życzliwości miejscowego proboszcza o. Kowalski pisał w cytowanym liście z 26 marca. Tuż po podpisaniu umowy 25 maja bp Przeździecki polecał administratorowi odpowiednie wprowadzenie swego następcy w aktualną sytuację parafii ${ }^{37}$. Tym razem nie obyło się bez drobnych niepokojów. O. Leonard Nandzik, mianowany nowym proboszczem, żalił się na usposobienie kuzynki ks. administratora Tuza - czyniła ona niemożliwym tymczasowe wspólne zamieszkanie oblatów i ks. administratora w jednej plebanii. Oblat dodawał: „Wobec tego proszę Waszą Ekscelencję najpokorniej o możliwe rychłe zwinięcie tejże żywej, a dla nas Oblatów bardzo nieżyczliwej gazety Kodeńskiej. Nawet obecność Wielebnego Ks. Tuza jest już na miejscu niepotrzebną, a jedynie z powyższego powodu nawet przykrą"38. Niepokoje związane ze zmianą duszpasterzy trapiły miejscową wspólnotę jeszcze jakiś czas. 30 sierpnia 1927 r. duża grupa parafian napisała do bpa Przeździeckiego list, dziękując mu za sprowadzenie do Kodnia wspólnoty zakonnej oraz deklarując, że głosy przeciwne związane były $\mathrm{z}$ prywatnymi interesami osób dotąd zaangażowanych przy obrabianiu parafialnej ziemi ${ }^{39}$.

Dla zewnętrznego obserwatora, nawet w szeregach zakonnych, zarysowany wyżej przebieg wydarzeń wydawać się mógł zaskakujący i opatrznościowy: niespodziewana propozycja biskupa siedleckiego, zgłoszona z końcem stycznia, doprowadziła w ciągu kilku miesięcy do objęcia przez młode i wciąż stosunkowo

\footnotetext{
${ }^{34}$ Codex historicus - Kodeń, w: J. KRAWCZYK, Źródta, t. 8, Lublin 1968, mps w APP, s. 32.

${ }^{35}$ Oba dokumenty zob. APP, Domy Prowincji, Kodeń /I/.

${ }^{36}$ Zob. Umowa pomiędzy J.E.Ks. Biskupem Podlaskim a W.O. Prowincjałem Zgromadzenia Misjonarzy Oblatów Maryi Najświętszej i Niepokalanej Marji Panny w Polsce, w sprawie objęcia przez tychże OO. Oblatów kościoła i parafii w Kodniu, diecezji Podlaskiej. Tamże.

${ }^{37}$ H. Przeździecki do S. Tuza, Siedlce, 27 V 1927, ADS, Kuria/OMI.

${ }^{38}$ L. Nandzik do H. Przeździeckiego, Kodeń, 3 VII 1927, ADS, Kuria/OMI.

${ }^{39}$ Parafianie kodeńscy [liczne podpisy] do H. Przeździeckiego, Kodeń, 30 VIII 1927, ADS, Kuria/OMI.
} 
mało znane w Polsce zgromadzenie zakonne ważnego i historycznego sanktuarium Maryjnego w Kodniu. Dwa fakty dodatkowo wyjaśniają powód zainteresowania bpa Przeździeckiego właśnie Zgromadzeniem Misjonarzy Oblatów Maryi Niepokalanej w kontekście przyszłości sanktuarium i parafii w Kodniu. Jak zapisał to po wielu latach w odtwarzanej kronice kodeńskiej o. Franciszek Kowalski:

bp Przeździecki powziąwszy postanowienie oddania Kodnia jakiemuś zakonowi - podobno po otrzymaniu odmownej odpowiedzi XX. Jezuitów i XX. Marianów - był w Rzymie. Zwiedzając kościół Dwunastu Apostołów czy też kościół Santa Maria sopra Minerva - spotkał tam ks. biskupa Galla, któremu się zwierzył ze swego kłopotu z wyborem zakonu dla Kodnia. Ks. biskup Gall miał mu wtedy stanowczo radzić, by zgłosił się do OO. Oblatów, których jako biskup polowy poznał w Lublińcu, gdzie był częstym gościem. Ks. bp Przeździecki poszedł wtedy za radą ks. bpa Galla ${ }^{40}$.

Ponadto, uprzedzając nieco propozycję bpa Przeździeckiego, 15 stycznia 1927 r. z prośbą o udzielenie stałej jurysdykcji do głoszenia misji w diecezji siedleckiej zwrócił się doń o. Jan Kulawy ze wspólnoty misyjnej w Krobi ${ }^{41}$. Biskup siedlecki udzielił zgody pismem z 18 stycznia, prosząc jednocześnie o spotkanie z wyższym przełożonym oblatów w związku z planem powierzenia Zgromadzeniu placówki (nazwa nie została w liście wymieniona) ${ }^{42}$. To właśnie Jan Kulawy reprezentował prowincjała na owym styczniowym spotkaniu, podczas którego pojawiła się propozycja objęcia przez oblatów sanktuarium i parafii kodeńskiej.

Oblaci od samego początku z dużą nadzieją podjęli propozycję biskupa ${ }^{43}$. W połowie lutego o. Franciszek Kowalski odbył swoją pierwszą podróż do wschodniej Polski, żeby naocznie zapoznać się z sytuacją, w jakiej znajdował się wówczas Kodeń, jego kościoły i zabudowania parafialne. Wspominał po latach: „Gdy za Warszawą, a szczególnie za Mińskiem Mazowieckim widziałem pola i lasy śniegiem pokryte, wioski i pojedyncze zabudowania, miałem wrażenie, że jestem w Kanadzie"44 - tam rzeczywiście o. Kowalski stawiał swe pierwsze duszpasterskie kroki, przed powrotem do kraju w związku z tworzeniem się struktur Polskiej Prowincji Misjonarzy Oblatów Maryi Niepokalanej. 15 marca Rada Generalna w Rzymie wydała wstępną zgodę na objęcie nowej placówki, która miała nastąpić

\footnotetext{
${ }^{40}$ Codex historicus - Kodeń, s. 33.

${ }^{41}$ J. Kulawy do H. Przeździeckiego, Krobia, 15 I 1927, ADS, Kuria/OMI. Por. Codex historicus - Kodeń, s. 31.

${ }^{42}$ H. Przeździecki do J. Kulawego, Siedlce, 18 I 1927, ADS, Kuria/OMI.

${ }^{43}$ Dalsza relacja w tym akapicie wg Codex historicus - Kodeń, s. 33nn.

${ }^{44}$ Codex historicus - Kodeń, s. 33.
} 
wraz z ponownym umieszczeniem w kościele parafialnym obrazu Matki Bożej Kodeńskiej ${ }^{45}$.

W ten sposób skrzyżowały się dziejowe drogi odbudowy struktur diecezji siedleckiej oraz rozwoju Polskiej Prowincji Misjonarzy Oblatów. Dla zakonników szczególnie ważna była długa Maryjna tradycja Kodnia oraz otwarcie perspektyw apostolatu we wschodniej Polsce.

W pierwszym przypadku można mówić o zgodności oblackiego charyzmatu z osobistymi przekonaniami i pobożnością bpa Henryka Przeździeckiego. Jak wykazano w niedawnym studium, pierwszy biskup siedlecki odrodzonej Polski należał do grona biskupów, których posługiwanie przejawiało wyraźny rys Maryjny $^{46}$. W liście pasterskim z okazji kanonicznego objęcia diecezji biskup zawierzył swe posługiwanie Maryi, wzmiankując przemoc zaborców, którzy wywieźli z terenu diecezji obrazy Matki Bożej Kodeńskiej i Leśneńskiej. Modlił się: „dopomóż, błagam, abym Twe święte wizerunki na dawnych miejscach mógł umieścić, a Ty, Matko, byś dawnemi łaskami wśród nas napowrót zajaśniała»" W dniu powrotu obrazu Matki Bożej Kodeńskiej do Kodnia biskup ponownie dokonał aktu zawierzenia Maryi ${ }^{48}$. Katedra i dekanat siedlecki, noszące tytuł Niepokalanego Poczęcia Najświętszej Maryi Panny, powołanie do życia Stowarzyszenia Diecezjalnego Czcicieli Niepokalanie Poczętej Dziewicy, częste nauczanie o Niepokalanym Poczęciu Maryi ${ }^{49}$ - wszystko to każe myśleć o nieprzypadkowej decyzji powierzenia troski o duszpasterstwo w Kodniu Misjonarzom Oblatom Maryi Niepokalanej.

Upodobanie oblatów do misji odbudowy struktur kościelnych oraz służby ubogim także predestynowały Kodeń do roli miejsca o dużym znaczeniu dla młodej prowincji zakonnej. Cytowany wyżej wyciąg z protokołu posiedzenia

\footnotetext{
${ }^{45}$ Jak już wyżej zaznaczono, kwestia powrotu obrazu Matki Bożej Kodeńskiej z Jasnej Góry do Kodnia jest przedmiotem osobnego studium o. Leonarda Głowackiego OMI, zatem w niniejszym tekście nie poświęcam jej dodatkowych refleksji.

${ }^{46}$ R. KARWACKI, Miejsce Niepokalanej w postugiwaniu pasterskim biskupa Henryka Przeździeckiego, w: Niepokalana Matka Chrystusa. Materiaty z sympozjum mariologicznego, Lublin, 2324 kwietnia 2004 roku, red. K. Kowalik, K. Pek, Częstochowa-Lublin 2004, s. 169-177.

${ }^{47}$ Cyt. za: R. Karwacki, Miejsce Niepokalanej, s. 171.

${ }^{48}$ Tamże, s. 173

${ }^{49}$ Tamże, s. 172, 174, 175-177. Co ciekawe, autor - opisując miejsce Niepokalanej w posługiwaniu pasterskim biskupa - nie wspomniał o sprowadzeniu przezeń do swej diecezji Zgromadzenia Zakonnego Misjonarzy Oblatów Maryi Niepokalanej. W świetle jego refleksji zastanawia też fakt, iż w krótkim szkicu poświęconym „,miejscom szczególnym w diecezji siedleckiej” innego autorstwa (B. BŁoński, Diecezja siedlecka. Przeszłość i teraźniejszość, w: Przypatrzcie się bracia powołaniu waszemu, red. A. Baran, Lublin 2002, s. 129-143) obok Janowa Podlaskiego, Pratulina, Siedlec oraz Nowego Opola k. Siedlec zabrakło Kodnia i tak ważnego dla bpa Henryka Przeździeckiego sanktuarium Matki Bożej Kodeńskiej z jej cudownym obrazem.
} 
Rady Prowincjalnej zawiera określenie Kodnia jako potencjalnego „okna na wschód dla naszej prowincji..." Oznaczało to po pierwsze perspektywę realizacji pragnienia biskupa siedleckiego, by oblaci zaangażowali się w dzieło neounii. Po drugie zbliżało wspólnotę oblacką, dotąd skoncentrowaną w Wielkopolsce i na Śląsku, do wschodnich rubieży kraju, a więc znanych jako najuboższe w polskich realiach okresu międzywojennego ${ }^{50}$.

Pominę w tym miejscu typową dla sanktuarium i parafii obrządku łacińskiego działalność duszpasterską oblatów, która nabrała rozmachu po 4 września 1927 r. $^{51}$ Dodatkową kwestią związaną z Kodniem, nową dla oblatów w Polskiej Prowincji, choć nieobcą Zgromadzeniu w jego wymiarze międzynarodowym ${ }^{52}$, była konieczność zaangażowania w działalność ekumeniczną oraz pracę $\mathrm{z}$ katolikami obrządku wschodniego. O. Jan Nawrat w swych wspomnieniach podkreślił, iż „opieka nad wiernymi obrządku wschodniego należała do warunków objęcia Kodnia",53. Dodawał: „Pożądanym by było, aby nasza praca dla obrządku wschodniego była gruntownie opracowana przez tych, którzy temu apostolstwu się poświęcili" ${ }^{\text {"54. }}$. Niestety, takie opracowanie nie powstało, natomiast kwestię zaangażowania oblatów na rzecz neounii podjęli niedawno magistranci na seminarium historii Kościoła w Wyższym Seminarium Duchownym Misjonarzy Oblatów Maryi Niepokalanej w Obrze, pod kierunkiem autora niniejszego tekstu ${ }^{55}$. Podstawowym źródłem ich informacji pozostawał Codex historicus domu kodeńskiego, co postulat pogłębionych badań nad zaangażowaniem oblatów w neounię czyni nadal aktualnym. W tym miejscu wystarczy wspomnieć kilku przedwojennych oblatów, którzy krócej lub dłużej związali się z działalnością neounijną. Byli to m.in.: o. Edmund Porankiewicz, o. Józef Łopuszański, o. Władysław Łuczak, o. Michał Sułkowski, o. Antoni Potoczny, o. Jan Jastrzębski, o. Jan Panek, o. Karol Kubsz ${ }^{56}$. W latach

\footnotetext{
${ }^{50}$ Zob. P. LEMEKH, Misjonarze Oblaci Maryi Niepokalanej na terenie dzisiejszej Białorusi w latach 1934-1992, Poznań 2017, mps mgr, [Wydział Teologiczny UAM, promotor P. Zając OMI], s. 28.

${ }^{51}$ Zob. G. MARECKI, Dziatalność Misjonarzy Oblatów, s. 53nn [rozdział III pracy magisterskiej pt. Dziatalność oblatów w parafii kodeńskiej w latach 1927-1939].

${ }^{52}$ Jak przypomniał P. Lemekh w swej pracy magisterskiej, cytując przedwojenne oblackie relacje, „Już św. Eugeniusz de Mazenod jako biskup Marsylii prosił patriarchę antiocheńskiego o wysłanie kapłanów obrządku wschodniego dla wiernych gromadzących się przy jednym z kościołów Marsylii. Pierwszym oblatem, który przeszedł na obrządek wschodni, był o. Filip Roux w Kanadzie, który pracował wśród Rusinów - emigrantów z Europy wschodniej”. Zob. Misja wschodnia, „Oblat Niepokalanej" 1936, nr 7-8, s. 197-198. Cyt.: za P. LEMEKH, Misjonarze Oblaci, s. 39.

${ }^{53}$ J. NAWRAT, Mój życiorys $i$ wspomnienia, w: J. KRAWCZYK, Źródła, t. 11, Lublin 1972, mps w APP, s. 88 .

${ }^{54}$ Tamże.

${ }^{55} \mathrm{O}$ działalności neonunijnej oblatów w Kodniu oraz zainteresowaniu tą kwestią w całej prowincji pisali w cytowanych już pracach magisterskich G. Marecki, P. Lemekh, a także wspomniany niżej P. Osadnik.

${ }^{56}$ Zob. Codex historicus - Kodeń, s. 49-51; F. RZEMIENIUK, Kościót katolicki obrzadku bizantyjsko-stowiańskiego (neounia), Lublin 1999, s. 266; P. LEMEKH, Misjonarze Oblaci, s. 39-41.
} 
trzydziestych XIX w. w oblackich wyższych seminariach duchownych w Krobi i Obrze powstały kleryckie „,sekcje unijne koła misjologicznego”, wykazujące żywe zainteresowanie obrządkiem wschodnim ${ }^{57}$. I choć wśród oblatów - jak zresztą w skali całego Kościoła w Polsce - nie brakowało zarówno zwolenników, jak i przeciwników działalności neounijnej ${ }^{58}$, stwierdzić wypada, iż powierzenie oblatom parafii kodeńskiej wraz z obowiązkiem służby także w obrządku wschodnim na kilkanaście lat wpłynęło także na kierunki i priorytety rozwoju Polskiej Prowincji.

Dopełnia to obrazu wzajemnego przenikania się dróg odbudowy struktur diecezji siedleckiej po 1918 r. oraz rozwoju zupełnie nowych w Polsce struktur prowincji Misjonarzy Oblatów Maryi Niepokalanej począwszy od 1920 r. Obejmując 4 września 1927 r. sanktuarium i parafię kodeńską, oblaci włączyli się w realizację programu duszpasterskiego bpa Henryka Przeździeckiego. Biskup siedlecki ze swej strony, angażując oblatów w nowym dla nich kontekście tradycji i kultury chrześcijańskiej Podlasia i sąsiednich obszarów, dał impuls do poszerzenia zakresu misyjnego oddziaływania uczniów św. Eugeniusza de Mazenoda.

\section{ANEKS}

Dekret bpa Henryka Przeździeckiego o powierzeniu sanktuarium i parafii kodeńskiej Misjonarzom Oblatom Maryi Niepokalanej Źródło: „Wiadomości Diecezjalne Podlaskie” 9(1927), s. 333-334.

HENRYK PRZEŹDZIECKI

Dr Ś[więtej] T[eologii]

z Bożego zmiłowania i Ś. Stolicy Apostolskiej łaski

Biskup Siedlecki czyli Podlaski

Na wieczną rzeczy pamiątkę. Słynny Obraz Cudowny Matki Bożej Kodeńskiej długie już lata otacza pobożnością swoją nie tylko lud wierny tutejszej diecezji, lecz czci go cała Polska. Dzieje świadczą, że w niezwykły wprost sposób Obraz ten przywiózł Mikołaj książę Sapieha z Rzymu do Kodnia, a w roku 1636 wprowadzono go do kościoła kodeńskiego. Wierni obrządku łacińskiego i unickiego, a nawet i dysydenci napływali do Kodnia, by uczcić ten Obraz i wzywać pomocy Najświętszej Marii Panny. Papieże udzielali licznych

\footnotetext{
${ }^{57}$ Zob. P. OsADNIK, Karol Kubsz. Misjonarz Oblat Maryi Niepokalanej (1931-1966), Poznań 2016, mps mgr [Wydział Teologiczny UAM, promotor P. Zając OMI], s. 37-38.

${ }^{58} \mathrm{O}$ kontrowersjach z tym związanych informuje kodeński Codex historicus, s. 49-68. Zob. także K. GRZESIAK, J.R. MARCZEWSKI, Biskup lubelski Marian Leon Fulman wobec ruchu neounijnego, w: Pater Ecclesiae Lublinensis. Studia w 65. rocznice śmierci biskupa Mariana Leona Fulmana (1866-1945), red. J.R. Marczewski, Lublin 2010, s. 49-76.
} 
łask świątyni kodeńskiej. Za pozwoleniem zaś Stolicy Apostolskiej biskup łucki Stefan Rupniewski dokonał uroczystej koronacji Obrazu Matki Boskiej Kodeńskiej w dniu 15 sierpnia 1723 roku. Cześć Najświętszej Dziewicy przed tym znakomitym Obrazem ustawicznie wzrastała. Szczególną i rzewną pobożnością wierni obojga obrządków otaczali ten Obraz, a nawet dysydenci zza Buga śpieszyli odwiedzać Najłaskawszą Matkę i nie brakowało takich, którzy tu powracali na łono prawdziwego Kościoła. Rząd rosyjski dla poparcia schizmy w r. 1875 zagarnął świątynię kodeńską i kazał Obraz usunąć do Częstochowy. Z wielkim bólem serca patrzyli na to wierni i cierpieli. Odtąd Obraz Matki Bożej Kodeńskiej przechowywano w klasztorze Jasnogórskim w Częstochowie, a OO. Paulini stali na straży tej świętości. Uciskani przez schizmę Podlasiacy potajemnie udawali się do Częstochowy i tam wzywali Bogarodzicy Kodeńskiej do zachowania jedności ze Stolicą Apostolską.

Od chwili objęcia Naszego urzędu pasterskiego w tej diecezji najgoręcej pragnęliśmy i teraz pragniemy tego, by kościół w Kodniu przywrócić do dawnej świetności i Drogi Obraz Cudowny Bogarodzicy na nowo wprowadzić do Kodnia. Tedy w roku 1920 erygowaliśmy, a raczej przywróciliśmy parafię w Kodniu. Zatroszczyliśmy się o to, ażeby naprawiono i wedle sił przywrócono w kościele kodeńskim to wszystko, co straszliwa wojna wyrządziła, by w ten sposób przygotować wedle możności świątynię na przyjęcie Obrazu Przesławnego Bogarodzicy, którą pragnęliśmy wprowadzić na tron Jej łaski do Kodnia w odpowiedniej uroczystej procesji.

Dokonaliśmy z miłosierdzia Pańskiego pomyślnie tego zamierzenia, a teraz za niezbędne uważamy to, by zadość uczynić potrzebom czci należnej Najświętszej Dziewicy Marii w Kodniu, jako też zapewnić wiernym pracowitą posługę przez odpowiednich kapłanów, którzy by na miejscu zamieszkali i pracowali. W tym celu niniejszym dekretem, na wieczne czasy wydanym, zgodnie z kanonami 496, 498, 630-631, 1411 2-o, 1425 §2, oddajemy kościół w Kodniu a zarazem parafię wraz ze wszystkimi budynkami i dobrami tegoż kościoła i parafii Kongregacji Misjonarzy Oblatów Najświętszej i Niepokalanej Dziewicy Marii, posiadającym dom swój prowincjalski w Polsce, zarazem powierzamy ich szczególnej pieczy i straży Obraz Matki Boskiej Kodeńskiej, a czynimy to na warunkach, wymienionych w umowie szczególnej, zawartej i podpisanej w dniu 25 maja 1927 roku przez Nas i Przełożonych tejże Kongregacji.

Oby Bóg raczył wzmacniać najlitościwiej darami niebieskimi to dzieło zbożne, znakomite i tak doniosłe dla zbawienia dusz ludzkich, a Najświętsza Dziewica niech strzeże i broni tego najłaskawszą opieką swoją w Kodniu.

Usilnie prosimy i błagamy przed tronem miłosierdzia Pańskiego, ażeby prawdziwa wiara i szczera pobożność do Bogarodzicy ustawicznie wzrastała w tych, którzy do Kodnia napływać będą, by pobożnie uczcić Obraz Cudowny, ażeby też, jak niegdyś, tak też i obecnie, dysydenci wrócili do jedności świętej Matki Kościoła.

Na dowód czego etc.

Dan. w Kodniu, dnia 4 września 1927 roku.

+ Henryk biskup. 


\title{
BIBLIOGRAFIA
}

\author{
ŹRÓDŁA
}

Archiwum Diecezjalne w Siedlcach:

- Akta Kurii Diecezji Podlaskiej, Zgromadzenie Misjonarzy Oblatów w Kodniu, N.Z.8.

Archiwum Polskiej Prowincji Misjonarzy Oblatów Maryi Niepokalanej w Poznaniu

- Domy Prowincji, Kodeń /I/.

KRAWCZYK J., Źródta, Lublin 1968-1978, t. 11.

\section{OPRACOWANIA}

Aleksandrowicz P., Diecezja Siedlecka czyli Podlaska. W 150 rocznice erekcji (1818-1968). Przyczynki i materiały do dziejów Diecezji Siedleckiej czyli Podlaskiej, Siedlce 1971.

BALICKI L., Dzieje gospodarcze diecezji siedleckiej, 1918-1939, Lublin 1991.

BŁoŃski B., Diecezja siedlecka. Przeszłość i teraźniejszość, w: Przypatrzcie się bracia powołaniu waszemu, red. A. Baran, Lublin 2002, s. 129-143.

DMowski R., Unitis Viribus. Diecezja Podlaska w II Rzeczypospolitej, Warszawa 2013.

GŁowaCKI L., Wywiezienie i powrót Matki Bożej Kodeńskiej. Opowieść historyczna z okazji 90. rocznicy powrotu Obrazu Matki Bożej Kodeńskiej z Częstochowy do Kodnia [praca przygotowywana do druku, mps w posiadaniu autora].

GRZESIAK K., MARCZEWSKI J.R., Biskup lubelski Marian Leon Fulman wobec ruchu neounijnego, w: Pater Ecclesiae Lublinensis. Studia w 65. rocznice śmierci biskupa Mariana Leona Fulmana (1866-1945), red. J.R. Marczewski, Lublin 2010, s. 49-76.

JASTRZĘBSKI J., Kodeń. Szkic historii parafii katolickiej, b.m., 1985, [mps w Bibliotece WSD Misjonarzy Oblatów Maryi Niepokalanej w Obrze].

KARWACKI R., Miejsce Niepokalanej w postugiwaniu pasterskim biskupa Henryka Przeździeckiego, w: Niepokalana Matka Chrystusa. Materiaty z sympozjum mariologicznego, Lublin, 23-24 kwietnia 2004 roku, red. K. Kowalik, K. Pek, Częstochowa-Lublin 2004, s. 169-177.

LEMEKH P., Misjonarze Oblaci Maryi Niepokalanej na terenie dzisiejszej Białorusi w latach 19341992, Poznań 2017, mps mgr, [Wydział Teologiczny UAM, promotor P. Zając OMI].

MARECKI G., Działalność Misjonarzy Oblatów Maryi Niepokalanej w Kodniu w latach 1927-1939, Poznań 2009, mps mgr [Wydział Teologiczny UAM, promotor P. Zając OMI].

MATwIEJuK K., Błogosławieni Męczennicy Podlascy, Siedlce 1997.

OsadNiK P., Karol Kubsz. Misjonarz Oblat Maryi Niepokalanej (1931-1966), Poznań 2016, mps mgr [Wydział Teologiczny UAM, promotor P. Zając OMI].

PIElORZ J. OMI, Oblaci polscy. Zarys dziejów prowincji 1920-1970, Rzym 1970.

Pielorz J., Obraz Matki Boskiej Kodeńskiej na tle legendy i historii, Liège-Rzym 1996.

PRZEŹDZIECKI H., Listy pasterskie i przemówienia, 1928-1938, Siedlce 1938.

RZEMIENIUK F., Kościót katolicki obrzqdku bizantyjsko-stowiańskiego (neounia), Lublin 1999.

ZAJĄC P. OMI, „,Wobec wielkich potrzeb naszego wychodźstwa...”. Polscy Misjonarze Oblaci Maryi Niepokalanej w perspektywie Kapituty Generalnej 1926 r., ,Studia Polonijne” 33(2012), s. 117-140.

ZAJĄC P. OMI, Fundacje klasztorów Misjonarzy Oblatów Maryi Niepokalanej w Archidiecezji Poznańskiej w latach 1922-1939, „Ecclesia. Studia z dziejów Wielkopolski” 5(2010), s. 147-171. 
ZAJĄC P., Badania historyczne w polskim środowisku Misjonarzy Oblatów Maryi Niepokalanej, „Roczniki Historii Kościoła” 3(2011), s. 147-170.

ZAJĄC P., OMI, Fundacje klasztorów Misjonarzy Oblatów Maryi Niepokalanej w Archidiecezji Poznańskiej w latach 1922-1939, „Ecclesia. Studia z dziejów Wielkopolski” 5(2010), s. 147-171.

\author{
DUCHOWE IUNCTIM. POWIERZENIE PRZEZ BISKUPA SIEDLECKIEGO \\ HENRYKA PRZEŹDZIECKIEGO PARAFII I SANKTUARIUM W KODNIU \\ MISJONARZOM OBLATOM MARYI NIEPOKALANEJ W 1927 R.
}

\title{
Streszczenie
}

Terytorium diecezji siedleckiej było w drugiej połowie XIX w. świadkiem surowych prześladowań religijnych. Rząd carski konfiskował katolickie kościoły i zmuszał unitów do wyrzekania się unii z biskupem Rzymu i przechodzenia na prawosławie. Siedemnastowieczny wizerunek Matki Bożej Kodeńskiej został wywieziony z Kodnia do sanktuarium jasnogórskiego. Dopiero odzyskanie przez Polskę niepodległości w 1918 r. pozwoliło rozpocząć proces przywracania tradycyjnych kościelnych struktur. W artykule ukazane jest zaangażowanie bpa sieleckiego Henryka Przeździeckiego w sprowadzenie obrazu Matki Bożej Kodeńskiej z powrotem do Kodnia oraz powierzenie parafii i sanktuarium w Kodniu Misjonarzom Oblatom Maryi Niepokalanej. Początki duszpasterstwa oblatów nie wykluczały zaangażowania w odtwarzanie struktur Kościoła unickiego.

Słowa kluczowe: Kodeń; prześladowania religijne; Siedlce; Bp Henryk Przeździecki; Misjonarze Oblaci Maryi Niepokalanej. 